Volume-VI, Number-01, January-June, 2011

\title{
Business Analysis of Pharmaceutical Firms in Bangladesh: Problems and Prospects
}

\author{
MD. ANAMUL HABIB* \\ MD. ZAHEDUL ALAM**
}

\begin{abstract}
The aim of the study is to present the current scenario of the pharmaceutical industry in Bangladesh. Since inception, there was little consensus on the development of pharmaceutical policies best suited in a developing country such as Bangladesh. Here, the pharmaceutical industry developed rapidly from the 1980s after the introduction of Drug (Control) Ordinance-1982. Adequate infrastructure and use of trained manpower were two essential requisites for implementation of national pharmaceutical policies in Bangladesh. The country was importing significant amount of medicine and also raw materials for the industry from abroad. But the industry has started to export its products in foreign market, especially in the Middle East and Europe with great success. This study tries to identify the major problems of marketing, exporting, production and operations, quality control in the pharmaceutical sector and proposes strategies to overcome these problems, it also identifies the prospects of pharmaceutical industry in Bangladesh.
\end{abstract}

Keywords: Drug, Problem, Education, Health, Policy, Pharmaceutical, Deficit, Facilities, Executives.

\section{INTRODUCTION}

The pharmaceutical sector is one of the thrust sectors in Bangladesh. Before Liberation, there was hardly any pharmaceutical enterprise in Bangladesh (then East Pakistan). After several years of liberation, the government could not increase (in relative terms) budgetary allocations for the improvement of health sector. At that time, most of the people had little access to the essential lifesaving medicines. This sector started to improve from 1980s. The pharmaceutical industry has grown in the last two decades at a considerable rate (http://banglapedia). After the promulgation of Drug Control Ordinance-1982, the development of pharmaceuticals industry has accelerated. The skills and

\footnotetext{
* MD. Anamul Habib, Senior Lecturer, School of Business Studies, Southeast University, Dhaka.

Md. Zahedul Alam, Assistant Professor of Marketing, Department of Business Administration, Northern University Bangladesh, Dhaka.
} 
knowledge of the professionals and innovative ideas of the people involved in this industry are the key factors for these developments. Due to recent development of this sector, the country is exporting medicines to global market including European coutnries and on the top of it, the industry has been supplying about 95 per cent of the domestic demand for medicines. (http://www.pharmadu.net).

There are three drug manufacturing units under control of the Government of Bangladesh. Two of them are in Dhaka and another one is in Bogra. The name of these units is Essential Drug Company Ltd. (EDCL), which is operating as a public limited company under the Ministry of Health and Family Welfare. Essential Drug Company Limited produced medicines worth Tk. 964 million in 2000. The production rate of these companies is also increasing day by day. There are separate vaccines and large volume IV fluids production units under the Institute of Public Health (IPH) located in Dhaka. The medicines and other drugs like- vaccine of both Essential Drug Company Limited and Institute of Public Health are mostly used in government hospitals and institutions. In 2000, there were 261 unani, 161 ayurvedic, 76 homeopathic and bio-chemic licensed manufacturing units in Bangladesh. The total worth of their medicines was Tk 1.2 billion in 2000 .

One of the major positive impacts of Drug (Control) Ordinance-1982 is the rapid development of local manufacturing capability. In recent years, the country has achieved large volume of parental products, by which the country becomesself sufficient; huge volume of these products are also exported to other countries. The development of local manufacturing companies helped to reduce the dependence on the import of raw materials of pharmaceutical products and finished pharmaceutical products. Under the Drug (Control) Ordinance 1982, the Government determines Maximum Retail Prices (MRP) of 117 essential drug chemical substances. This price determination is only for the local producer companies and still now the multinational organizations are determining their price by their own way. For imported finished products, Government determines the fixed percentage of markup, but the (governmental) drug administration could not fix up the MRP in Bangladeshi market. It is interesting to note that, even with withdrawal of price control from many products, prices have not shot up; healthy competition has been keeping the prices within affordable levels.

\section{LITERATURE REVIEW}

At the global level, highly valuable studies are available on pharmaceuticals industry and related sectors. Specific studies on Bangladesh pharmaceuticals industry are limited. 
Infrastructure development and the deployment of trained manpower are now perceived as two of the essential prerequisites for the implementation of national pharmaceutical policies (Jayasuriya, 1991). Pharmaceuticals have greatly improved health in developing countries, but many people in developing countries do not obtain even inexpensive pharmaceuticals and little pharmaceutical $R \& D$ is oriented towards products needed by developing countries, such as a malaria vaccine and access to existing products could be improved by facilitating differential pricing (Kremer, 2002). It is suggested that under conditions of rapidly changing demand (as found in pharmaceuticals), price-caps could be manipulated and using simulations. The recent acquisition of the German pharmaceuticals and diagnostics company Boehringer Mannheim by F Hoffmann - La Roche illustrates how such huge business transactions meet with trade unions which are completely unprepared (Zeller, 2000). The number of new drugs approved in the United States each year is huge that is readily available, but it is known that no systematic analyses of the long-term patterns of new drug approvals by firm have been reported in the literature (DiMasi, 2000). The United States has a clear edge both in terms of "output", in other words, the number of new active ingredients for pharmaceuticals, and in terms of "input", that is, R\&D spending of US\$ 20 billion on drug development in that country every year (Humer, 2005). 'The pharmaceutical industry arguably has the worst record of serious corporate crime of any industry, international law evasion rather than outright law violation has been the biggest problem in the industry. Consumer and professional activism and a variety of levels of selfregulation in combination with state, regional, and international regulation are all important to understanding how progress is possible (Braithwaite, 1993)'. Though some significant problems are prevailing in this sector, pharmaceutical industry in Bangladesh has achieved remarkable growth and has ample opportunity to grow in future (Shariat Ullah \& Razzak, 2006).

This study tries to investigate the different aspects of pharmaceutical industry of Bangladesh such as marketing, HR, export and import.

\section{OBJECTIVES OF THE STUDY}

The objectives of the study are:

- To present the current scenario of pharmaceutical industry in Bangladesh.

- To identify the problems and prospects in different areas of pharmaceutical industry.

- To suggest some policy guidelines for resolving these problems and to cope with the new regime of globalization. 


\section{METHODOLOGY OF THE STUDY}

This study has utilized both primary and secondary data. ten leading pharmaceutical firms have been selected for the study. Primary data have been collected from discussions with 110 concerned executives of different pharmaceutical companies, top level officials of different pharmaceutical companies, officials of the Directorate of Drug Administration (of Government of Bangladesh) and interviewing the customers of the drugs. The study utilizes different secondary industry-related data on export, import, marketing, human resources, dumping etc. which are collected from the website, annual reports of different pharmaceutical firms important research papers, magazines, relevant books, newspapers, journals, and other relevant documents.

\section{RESULTS AND DISCUSSIONS}

\section{Products}

Up to year 2000, there were 210 licensed allopathic drug-manufacturers in the country; of them only 173 actively produced the medicines while others were either closed down on their personal problems or by the authority for drugs administration due to non-compliance of drug laws. The manufacturers are now producing near about 5,600 brands of medicines in different forms. For promoting these products, there are 1,495 wholesale and around 37,700 retail drug license holders in different areas of Bangladesh. Anti-infective is the largest therapeutic class of locally produced medicinal products, distantly followed by antacids and anti-ulcer ants.

There are some other significant therapeutic classes including non-steroidal anti-inflammatory drug (NSAID), vitamins, central nervous system (CNS) and respiratory products. The local industry is extraordinarily increasing the production of basic chemicals. At present, there are 13 medicinal product manufacturing units, which also manufacture certain basic materials. These include paracetamol, ampicillin trihydrate, amoxycillin trihydrate, diclofenac sodium, aluminium hydroxide dried gel, dextrose monohydrate, hard gelatin capsule shell, chloroquine phosphate, propranolol hydrochloride, benzoyl metronidazole, sodium stibogluconate (stibatin) and pyrantel pamoate. However, most of these are restricted to the last stage of synthesis.

\section{Marketing}

Marketing is the process by which companies create value for customers and build strong customer relationships in order to capture value from customer in return (Kotler, 2005). Marketing is the backbone of all industries. Though pharmaceuticals produce life saving drugs, they also need marketing. But their 
marketing is to some extent different from other industries. Some major characteristics of marketing sector are given below:

- Their distributional channel includes invoice system, own distribution channel.

- Medical representatives are the key persons in marketing.

- For promotion, the groups such as doctors, surgeons are targeted.

- Major promotional strategies include printed promotional materials, physical sample, and clinical materials.

- Special incentives are given to the doctors. For example, the doctors are given honeymoon packages, the cost of which is borne by the pharmaceuticals.

The field level executives are playing the imperative role for marketing division. Basically, they have taken the responsibility to market the products of their companies. So, the success of a pharmaceutical industry intensively depends on the efficiency and effectiveness of the medical representatives. If an organization wants efficient employees in this section, he should to satisfy these representative.

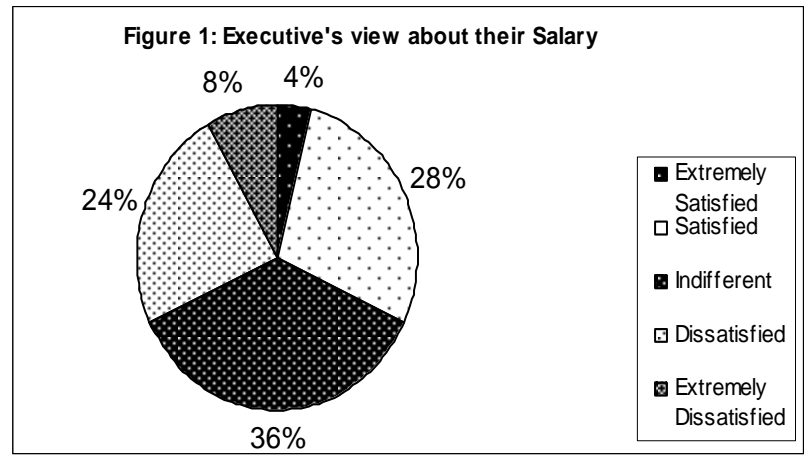

Source: Primary data collected by sample survey, 2009

The researcher conducted a small survey over the field level executives, who are playing the prime role for marketing of the products of pharmaceutical companies. Here, the study finds that, only 32\% employees are in satisfactory and extremely satisfactory level. So, how it is possible to expect, the executives will devote maximum effort for marketing their products. Most of the interviewees think that the sector should increase the benefits to the marketing executives with relevant effort. 


\section{Human Resources}

Human resources are people recruited in the organization and treated as the prime mover and an important element for success of any organization (DeCenzo \& Robbins, 2005). The sector consistently creates job opportunities, especially for highly qualified people. Pharmaceutical companies are either directly or indirectly contributing largely towards raising the standard of healthcare and standard of living byenabling local healthcare personnel to gain access to newer products and also to latest drug information.

Like other industries, pharmaceutical industry also believes that the human resources are most valuable asset for the organization. Pharmaceutical industry is making considerable investments in attracting and developing competent professional human resources. Pharmaceuticals not only foster entrepreneurship, but also consciously encourage entrepreneurship in their organizational environment. This leads to innovation and creativity transformed into new products, services and new ways of doing things. To get most effort strom human resources, pharmaceutical industries implement programs like decentralization, job enrichment and job rotation. The extent of empowerment enjoyed by people at various levels of the organization enables each employee from the very bottom to the top, to contribute to the overall momentum of the companies.

\section{Training and Development}

Training refers to instruction provided for a current job and has a rather narrow focus and should provide skills that will benefit the organization rather quickly. Development, on the other hand, has a broader scope and may not be focused on either the present or future job but more on the organization's general long-term needs (Anthony et al, 2003). Pharmaceutical industries are continuously striving to explore the necessary competences of the employees, especially the marketing executives to face the challenges of the competitive environment. They arrange different types of learning programs which are enforcing as a motivation too to upgrade necessary knowledge and skills of their employees. By interviewing the employees of different pharmaceuticals the researcher comes to know that they participated in various training programs that include: Pharmaceutical marketing situation beyond 2005, Company formation, regulatory compliance and company meeting, Industrial control and mechatronics, Continuous improvement and changing behavior, Presentation skills, General guidelines of Standard Operating Procedure (SOP), Sanitation, hygiene and environment control, Maintenance of equipments, calibration and validation, Industrial automation, etc. 


\section{Exporting}

Exports are goods and services produced by a firm in one country and then sent to another country (Rugman, 2004). To export products to developed markets, companies must bring their factories into conformance with GMP (Good Manufacturing Process) standards and by this process, the vast majority of Indian pharmaceutical exports went to other developing countries with similar disease profiles and disregard for patent protection (Smith, 2000). Export of pharmaceutical products of Bangladesh is still in infancy. But the rate of establishment of pharmaceuticals industries in private sector is increasing and they have already entered the export market with their finished products. In 2000, Bangladesh imported US\$84,000,000 worth of medicinal and pharmaceutical products and had negligible exports and some recent statements by industry representatives suggest that exports will increase in the near future (VanDuzer, 2003). Bangladesh is exporting their pharmaceuticals products to Vietnam, Singapore, Myanmar, Bhutan, Nepal, Sri Lanka, Pakistan, Yemen, Oman, Thailand, and some countries of Central Asia and Africa. It also has a large market in European countries.

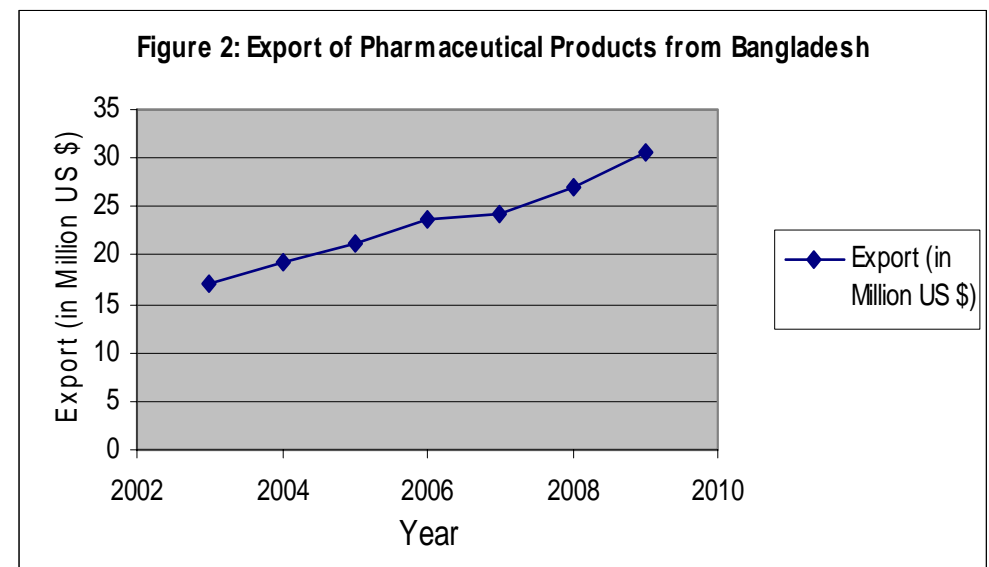

Source: Secondary data collected from Drug Administration, 2011.

From the above figure, it can be concluded that the trend of export is upward. According to the drug administration, Bangladesh could not export the expected amount of pharmaceuticals products in the year 2007 due to some political problems. Drug administration hopes that the trend will continue in future. 


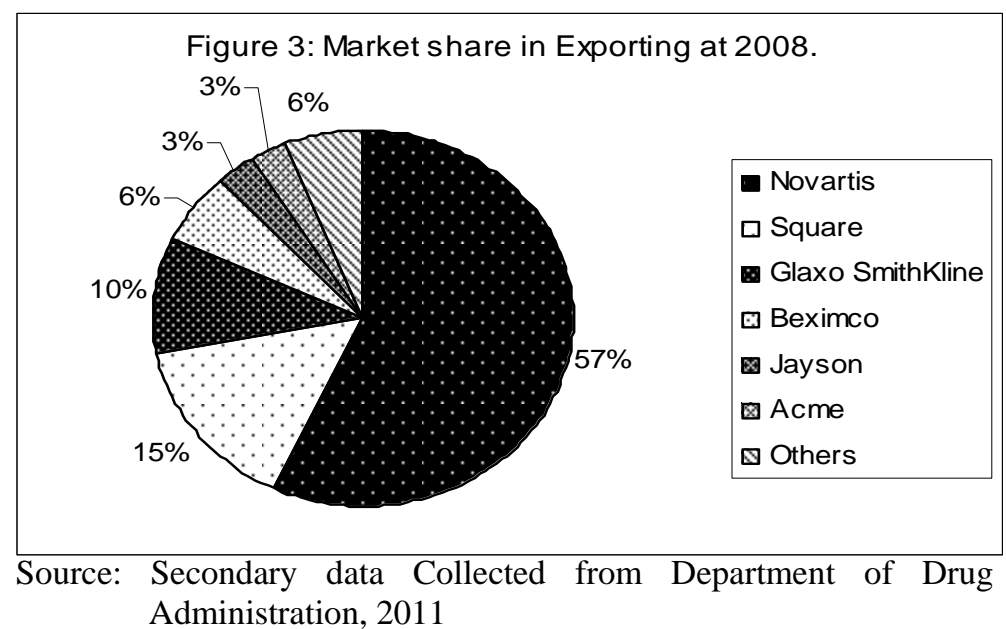

In Bangladesh, there are about 50 pharmaceuticals companies, who are leading the local market. But all of them are not engaged in exporting. The above figure gives a clear about the market share in export marketing from Bangladesh. Novartis is leader in export marketing. Though Novartis is a foreign organization and they remit their profit to their parent country, they are paying different types of tariffs and taxes to the government of Bangladesh.

\section{Importing}

Importing is acquiring or purchasing the goods or products which have been made in another country (Skinner \& Ivancevich, 2003). Bangladesh is importing the medicinal products from different countries, especially from India. Different organizations of this country are related to import the pharmaceuticals products and raw materials of pharmaceutical industries. Novo and Medintis are importing maximum amount of these types of products. Other organizations are engaging to import the pharmaceuticals products. They are- Sanofi, Aventis, Glaxo Smithkline, Sandoz, Novartis, Roche, Unimed, Servier etc.

TABLE 1

YEARLY CONSUMED COST OF MEDICINE AND IMPORTED COST

\begin{tabular}{c|c|c|c}
\hline Year & $\begin{array}{c}\text { Total Medicine } \\
\text { Consumption (in Million } \\
\text { US \$) }\end{array}$ & $\begin{array}{c}\text { Imported Amount (in } \\
\text { million US \$) }\end{array}$ & $\begin{array}{c}\text { Local Medicine (in } \\
\text { million US \$) }\end{array}$ \\
\hline 2005 & 498.5 & 23.43 & 475.07 \\
2006 & 512.06 & 28.27 & 483.79 \\
2007 & 536.42 & 34.8 & 501.62 \\
2008 & 552.58 & 33.15 & 519.43 \\
2009 & 567.3 & 35.78 & 531.52 \\
\hline
\end{tabular}

Source: Data collected from the file of Bangladesh Bureau of Statistics (BBS), 2011 
This chart explains that the consumption of medicine and imported amount of medicine is increasing year by year. In 2007, Bangladesh imported huge amount of medicine due to some political and social problems. The imported amount of 2008 is lower than the previous year. According to drug administration, the production was high in 2008. For this reason the imported amount was low and political unrest is the reason for increasing the imported amount and declining the exported amount in 2007.

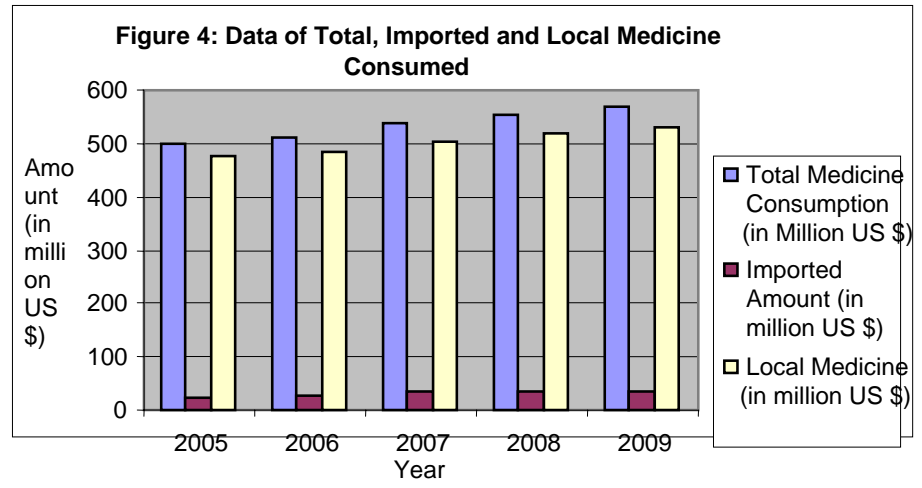

Source: Data collected from the file of Bangladesh Bureau of Statistics (BBS), 2011

From the above figure, it can be easily found that the maximum demand of medicine is met by the product produced by our locally established organization (locally owned and multinational). The production and imported amount are both increasing. Leaders of the owner's association of drug administration think that the government should take measures to impose tariffs and taxes on import that may encourage local pharmaceutical companies.

\section{Foreign Competitions}

At the beginning the foreign pharmaceuticals were dominating the market in our country. Still now, Pharmaceuticals industries are facing foreign competition. But our industry is not afraid of this foreign competition. There are many multinational pharmaceutical organizations which have established their plants in Bangladesh and importing their raw materials from abroad. Among these competitors, Roche, Glaxo SmithKline, Novartis are leading. In export market, the Novartis is playing the dominant role.

\section{Dumping}

Dumping is a situation when in which a company sells its products for lower prices than the market price to capture the market share (Griffin \& Pustay, 2001). From the top management of the pharmaceutical companies, we got to know that 
some Indian medicines are sold in the country market at a lower price than Bangladeshi medicines but the medicine of developed countries and their origin country are sold in a competitive price, even in higher price. This creates the barrier to capture the market share by Bangladeshi pharmaceutical industries. Owners of the pharmaceutical companies think that the government should take actions to stop this practice.

\section{Customer Choice}

Customer is a person who buys the products as well as consumes the products and consumer only consumes the products (Chowdhury, 2000). Pharmaceutical industries are dealing with life saving drugs; here customer choice does not change so rapidly. People may prefer one brand to another. But the medicine may carry the same compound/ same ingredients.

Customer choice depends on the customers' reliance upon the company. For example, Beximco's Napa, and Glaxo's Parapirol carry the same compound and used for the same purpose. But, the customer purchases one of them. Customers usually prefer some foreign medicine in case of sensitive problem. However, our local pharmacies do not produce all the sensitive drugs, especially injections.

This research also conducted a small survey over the customer of medicinal product and their choices. The sample was taken from different hospitals and pharmacy that came to buy the products.

TABLE 2

CUSTOMER'S CHOICE OF BRAND NAME

\begin{tabular}{lc}
\hline Brand Name & Respondent (in \%) \\
\hline Square & 38 \\
Beximco & 24 \\
Incepta & 16 \\
Glaxo SmithKline & 8 \\
Acme & 6 \\
SK-F & 4 \\
Others & 4 \\
\hline
\end{tabular}

Source: Primary data collected by sample survey, 2010.

The above chart represents the scenario of customer choice toward the brand name. Most of the customers choose their medicine produced by square pharmaceuticals limited. According to the customer choice, no organization can play dominant role in the market. 


\section{Research and Development}

Research is defined as the systematic and objective process of gathering, recording, and analyzing data for aid in making decision and development (Zikmund, 2005). Every organization is related to research \& development. The organization becomes backdated which is not related to update their product. In pharmaceutical sector, multinational corporations are more concerned about research and development than locally owned companies. The implication is that MNCs will need to find ways to increase their R\&D productivity, and it also means that Indian and Chinese firms with relatively novel approaches to product and process development may find opportunities opening up for them, whether through go-it-alone strategies or through co-operative R\&D partnerships with MNCs (Grace, 2004).

Pharmaceutical's R\&D team is committed to the development and introduction of novel drugs and drugs delivery systems that make them a frontrunner in the Pharmaceuticals industries. But budget for the research and development is not sufficient for appropriately doing this task. Research \& Development are the main reasons for the progressive consolidation of our industry \& fifteen years ago, the ten largest companies commanded 25\% of the global market; today their market share is over $50 \%$ for concerning R \& D (Humer, 2005). The R\& D team comprises of highly qualified and trained technical personnel continuously striving for product and process innovation and up gradation.

The sincere and relentless effort of the $\mathrm{R} \& \mathrm{D}$ team has taken the company a step further through introduction of high tech Anti-AIDS and Anti-cancer products in the recent years. A good number of APLs are also in the development pipeline to ensure availability of raw materials in the post WTO era. With their continuous investment in R\&D and cutting -edge technology, Pharmaceutical is moving forward to meet tomorrow's healthcare needs.

\section{Competitive Position}

Pharmaceutical industry is facing competitive market domestically. Square, Beximco, Incepta, Acme, SK-F, Drug International, AristoPharma, ACI, are the competitors of one another in medicine market. 


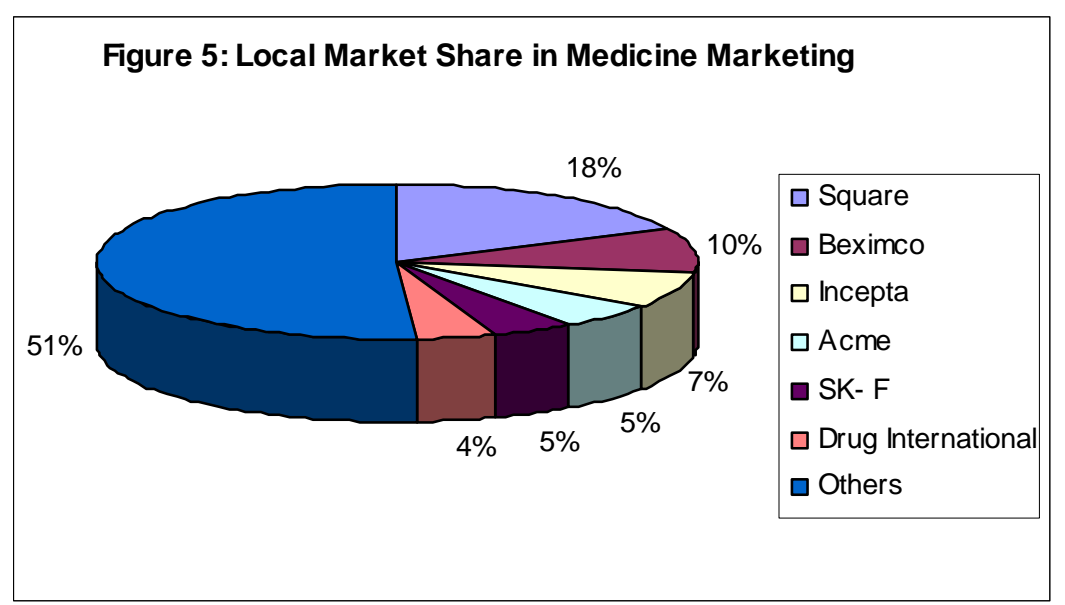

Source: Office of Bangladesh Association of Pharmaceutical Industry (BAPI), 2009.

To purchase the medicinal product is not depending on the customer choice. For this reason, the primary survey over the customer and the actual condition is different. From the above chart, this can be said that no organization can capture the maximum market share in medicine marketing. There is a tough competition among Square, Beximco, and Incepta.

\section{PROBLEMS AND PROSPECTS}

\section{Problems of Marketing}

i. Because of having no sufficient incentives in comparison with their effort, the turnover rate of medical representatives is very high.

ii. Most of the time costs of marketing hardly affect the price of the medicine.

iii. Professionalism in marketing is not achieved yet in Bangladesh like other developing countries.

iv. Lack of proper governmental laws and this implementation the law by the drug administration.

v. Unstable political situation and different types of violence.

vi. Effect of globalization that has increased the competition.

vii. Smuggled production counterfeit, that's coming from the neighbor countries. 


\section{Prospects of Marketing}

i. Marketing system is improving in this sector and proper marketing may help a firm to achieve the aim.

ii. For free and fair competitions marketing can play a major role.

iii. Marketing can be regarded one of the most important weapons to face the challenges of open market economy.

\section{Problems of Foreign Competition}

i. Foreign competitors have more equipment, technology and plant facilities than that of locally owned firms.

ii. Foreign competitors have their own local market so that they can absorb some losses here.

iii. Foreign competitors get government help in some cases.

\section{Prospects of Foreign Competition}

i. Foreign competitions made the country firms more eligible to face challenges that arose after the year 2005.

ii. Pharmaceuticals industries will become more efficient in producing medicine which may save our lives.

iii. The local firms will not face any rigorous problem in foreign countries as they are accustomed in competition with foreign firms.

\section{Problems of Export}

i. Unstable political situation is one of the vital reasons for not achieving the expectation in export.

ii. Problems of port (both sea and air) hinder the timely export.

iii. Irresponsibility of customs officers is a regular phenomenon which results in increase on the price and cost of medicine.

iv. Sometimes competition tends to follow unfair promotional activities.

v. Still now, the products of the pharmaceuticals industries of Bangladesh are not world class.

\section{Prospects of export}

i. Competition is increasing the quality of medicinal products.

ii. For surviving in the future, competitive environment is necessary.

iii. Competition reduces monopolistic attitude of the firms. As a result, the customers will be benefited by getting quality products. 
iv. Export brings foreign currencies for the country which is helpful for the reserve of the country.

\section{Problems of Customer Choices}

i. One main problem is in producing rare drugs foreign companies are ahead of us in terms of quality, experience and market share.

ii. Most of the time, to purchase the medicinal products is not depending on the customer choice. Customers buy their product according to the prescription of doctors.

\section{Prospects of Customer Choices}

i. By increasing quality, more customers as well as market share can be absorbed.

ii. By producing rare drugs at home, the country can save its foreign exchange.

iii. By extensive promotional activity, customer choice can be driven.

\section{Problems of Power Development}

i. Like other industries, there is a crucial problem faced by the pharmaceutical industries that is power generation problem. They are not getting power according to their demand.

ii. 'Red-Tapism' of govt. offices hinders the development of power generation sector, where the government is not taking effective actions.

iii. Lack of opportunity to supply the emergency power to smooth continuation of production in pharmaceutical sector.

\section{Prospects of Power Development}

i. By following all the rules and innovating alternative power supply source, this sector is entering the competitive market.

ii. Pharmaceuticals may open a big door of prospect in the foreign market.

\section{CONCLUSIONS}

The per capita consumption rate of medicine in Bangladeshi people is one of the lowest in the world. However, the industry has been a key contributor to the Bangladeshi economy since independence. Pharmaceutical industry is growing at an expected rate with the development of healthcare infrastructure and increase of health awareness and the purchasing capacity of people. Healthy growth is likely to encourage the pharmaceutical companies to introduce newer drugs and 
newer research products, while at the same time maintaining a healthy competitiveness in respect of most essential drugs.

\section{RECOMMENDATIONS}

The proposed suggestions may help the pharmaceutical industries to reduce the problems in different areas. These are as follows:

- The medical representative's turnover is not adequate and equitable. So, the organizations can take measures to increase the salary for the medical representatives.

- Advertising cost should be reduced and this is necessary to make the marketing people aware of their profession.

- The local pharmaceutical companies should produce quality product by using the updated equipment and raw materials, which can help them to acquire the market share.

- Pharmaceutical companies should produce world class medicine which may increase the demand for Bangladeshi drug in the world market.

- Industry should make the people aware of the local products and with that they should ensure the quality medicine to earn confidence.

- Pharmaceutical companies may take the initiative to generate the power for continuous supply of electricity.

- The pharmaceutical companies should not violate the law imposed by the government, which can hamper the trust of the people of the country.

- Organizations should produce their product in a hygienic environment and maintain the highest standard.

- Government should take measures or formulate some clear-cut rules to restrict the foreign pharmaceutical organizations to practise the concept of dumping in this country.

\section{REFERENCES}

Abbott T. A. (1995), "Price regulation in the pharmaceutical industry: Prescription or placebo?” Journal of Health Economics, Volume 14, Issue 5, December 1995, pp. 551-565.

Anthony W.P., Perrewe P.L., Kacmar K.M. (2003), "Human Resource Management: A Strategic Approach” Third Edition, The Dryden Press, Harcourt Brace College Publishers, pp. 322-338. 
Braithwaite J. (January, 1993), "Transnational Regulation of the Pharmaceutical Industry" Annals of the American Academy of Political and Social Science, Vol. 525, White-Collar Crime, pp. 12-30.

Chowdhury A. I., (2000), “Consumer Behavior” School of Business, Bangladesh Open University, pp. 1- 13.

DeCenzo D.A., Robbins S.P. (2005), "Human Resource Management” Seventh Edition, John Wiley \& Sons, Inc. pp. 34-45.

DiMasi J. A. (2000), "New Drug Innovation and Pharmaceutical Industry Structure: Trends in the Output of Pharmaceutical Firms" Drug Information Journal, Vol. 34 pp. 1169-1194.

Grace C. (June, 2004), “The Effect of Changing Intellectual Property on Pharmaceutical Industry Prospects in India and China: Considerations for Access to MedicinesIssues paper - Access to medicines, DFID Health Systems Resource Centre, PP. 1-69.

Griffin R.W., Pustay M.W. (2001), "International Business: A Managerial Perspective” Third Edition, Pearson Education, Inc. Upper Saddle River, PP. 72-98.

http://banglapedia.search.com.bd/HT/P_0154.htm (Retrieved on: December 03, 2009).

http://www.pharmadu.net/bps/companyinfo.htm (Retrieved on: December 10, 2009).

Humer F.B. (16 March, 2005), "Innovation in the Pharmaceutical Industry -Future Prospects” Talk by Dr Franz B. Humer, Chairman of the Board of Directors and CEO of F. Hoffmann-La Roche Ltd, to the Zürcher Volkswirtschaftliche Gesellschaft Zurich, pp. 1-8. Industrial Policy, 1999.

Jayasuriya D. C. (December, 1991), "Pharmaceuticals and Developing Countries: Problems and Prospects” Pharmacy World \& Science, Springer Netherlands, Volume 13, Number 6/, 1991, pp. 244-247.

Kotler P. and Armstrong G. (2005), "Principles of Marketing” Tenth Edition, PrenticeHall, India Private Company Limited, New Delhi, pp. 1-12.

Kremer M. (2002), "Pharmaceuticals and the Developing World” American Economic Association, The Journal of Economic Perspectives, 16, Number 4, 1 November 2002 , pp. 67-90(24).

Rugman A.M. \& Hodgetts R.M. (2004), “International Business” Third Edition, Pearson Education (Singapore) Pte. Ltd, Indian Branch, pp. 1-5.

Shariat Ullah M., Razzak B.M., (2006), "Problems and Prospects of Pharmaceutical Industry in Bangladesh” Journal of Business and Technology, Vol. 01, Issue 01, January- June, 2006, pp. 35-44.

Skinner S.J., Ivancevich J.M. (2003), "Business for the $21^{\text {st }}$ century” Richard D. Irwin, Inc. USA, pp. 195- 204.

Smith S.E. (May, 2000), “Opening Up to the World: India’s Pharmaceutical Companies Prepare for 2005" Asia/Pacific Research Center, Institute for International Studies, Stanford University, pp. 1-46. 
VanDuzer T. (April, 2003), "TRIPS and the Pharmaceutical Industry in Bangladesh: Towards a National Strategy" CPD Occasional Paper Series, pp. 1-44.

Zeller C. (2000), "Rescaling Power Relations between Trade Unions and Corporate Management in a Globalizing Pharmaceutical Industry: the case of the acquisition of Boehringer Mannheim by Hoffman - La Roche" Environment and Planning Act. 32(9) pp. 1545 - 1567. 